\title{
MENTAL WORKLOAD AND ERGONOMIC ANALYSIS ON PRODUCTION DEPARTMENT AT PT. XYZ
}

\author{
Pashya Yafi Dhiya ${ }^{1 *}$, Devi Maulida Rahmah ${ }^{2}$ \\ Student of Department of Agro-Industrial Technology, Universitas Padjadjaran ${ }^{1}$ \\ Lecturer of Department of Agro-Industrial Technology, Universitas Padjadjaran² \\ Email: pashyafi@gmail.com
}

\begin{abstract}
This research aims to identify mental workload with NASA-TLX (Task Load Index) on packaging division and work posture on processing division at PT. XYZ. This research uses RULA (Rapid Upper Limb Assessment) and REBA (Rapid Entire Body Assessment) methods for work posture analysis. NASA-TLX is used to determine mental workload in packaging division. RULA is used to determine the upper body musculoskeletal disorders (MSDs) injury in the process of production (which consists of weighing and processing station) at PT. XYZ and REBA is used to determine entire body MSDs injury in the production process. Those methods are applied to indicate that the workers are in fact working above the safety limit. Based on NASA-TLX method, it is clear that 21 of 30 workers feel that the work is very heavy. Another case, two unusual postures are found, one is determined by the action level of the worker who lifting $20 \mathrm{kgs}$ sack of powder is 10 , so the action level of REBA, in this case, is hardly dangerous. The other one is determined by a worker who entering an ingredient to the machine, weight of the ingredient is 17,05 kgs. It means more than $10 \mathrm{kgs}$, and thus it can affect body posture.
\end{abstract}

Keywords: Ergonomics, NASA-TLX (Task Load Index), REBA (Rapid Entire Body Assessment), RULA (Rapid Upper Limb Assessment)

\section{INTRODUCTION}

Sutalaksana et al [1] explained that good companies give good services to their workers. Fernandez and Goodman [2] said that good ergonomics practice means increasing productivity, accomplished goals, achieving healthy and safe workers, and also improving job satisfication level.

Industries have higher production rate than any other businesses, so it increases the frequency of lifting, carrying, pushing or pulling loads that workers do. Industries mean that workers do work more than 8 hours to earn more money. It creates physical stress on the workers' bodies, which can lead to musculoskeletal injury [3]. Halim et al said that industrial workers are easier to feel discomfort and pain at work, so these problems are lead the workers to acquire health problems [4]
Putri [5] explained that there are three classifications of fatigue. One is based on the time during workers in the workplace. The second one is based on the process in muscle. And the last one is based on its cause. Factors of fatigue are physical and psychological in office, physiological, and physical exhaustion happened due to physical work, psychological fatigue, and other factors.

Physical exhaustion can be seen by using postural analysis technique which assess work activities. This analysis method records postures of workers so it shows the risk level of musculoskeletal injury in workplace.

The risk level of musculoskeletal injury can be assessed by two ergonomics methods, which are RULA (Rapid Upper Limb Assessment) [6] and REBA (Rapid Entire Body Assessment)[7].

Physical exhaustion can be measured by NASA-TLX (Task Load Index) method. 
This method will calculate the mental workload which is subjective by the workers and convert the result into numbers by NASA TLX. Thus, the subjective matter will become an objective number. This method is easier to define the mental workload compared to other methods [8].

PT. XYZ is one of the biggest cosmetics companies in Indonesia, so it employs many workers and has numerous factories. The company earns so much money, so this company has ability to buy good machines, but the machines have its problem. These machines do not designed to adapt with the average height of workers. So, these machines have ability to injure workers body if the workers working with these machines for a long time.

Several workers complained about the pain developed in their bones and muscles area, because of their habits during working. So, RULA and REBA exist to help reduce the level of complaints.

\section{RESEARCH METHODOLOGY}

This research was held in a local cosmetic factory which has organic ingredients in its products. The factory produces cosmetics such as lipstick, lip balm, shampoo, foundation, day cream, night cream, massage oil, etc. These data were collected through field observation and deep interview of the workers.

In this case, there are three methods to measure mental workload and body posture, namely:

1. NASA-TLX (Task Load Index) is a method used to identify mental workload, so it can improve a better way to do works without having stress.

There are several steps to measure NASA-TLX for mental workload, which are:

a. NASA-TLX Rating Scale Definitions Each category on NASA-TLX rating scale provides an explanation, so the respondents will be able to know which answer that fits with them.

The respondents were brought to choose answers that felt appropriate to the real situation. This rating scale can be seen at Table 1.

Table 1. NASA-TLX RATING SCALE DEFINITIONS

\begin{tabular}{ccl}
\hline Title & Endpoints & \multicolumn{1}{c}{ Descriptions } \\
$\begin{array}{c}\text { Mental } \\
\text { Demand (MD) }\end{array}$ & Low/High & $\begin{array}{l}\text { How much mental and perceptual activity was required (e.g., } \\
\text { thinking, deciding, calculating, remembering, looking, searching, } \\
\text { etc.)? Was the task easy or demanding, simple or complex, etc.? }\end{array}$ \\
\hline $\begin{array}{c}\text { Physical } \\
\text { Demand (PD) }\end{array}$ & Low/High & $\begin{array}{l}\text { How much physical activity was required (e.g.. pushing, pulling, } \\
\text { turning, controlling, activating, etc.) Was the task easy or } \\
\text { demanding, slow or brisk, slack or strenuous restful or laborious? }\end{array}$ \\
\hline $\begin{array}{c}\text { Temporal } \\
\text { Demand (TD) }\end{array}$ & Low/High & $\begin{array}{l}\text { How much time pressure did you feel due to the rate or pace at } \\
\text { which the tasks or task elements occurred? Was the pace slow } \\
\text { and leisurely or rapid and frantic? }\end{array}$ \\
\hline $\begin{array}{c}\text { Performance } \\
\text { (OP) }\end{array}$ & Good/Poor & $\begin{array}{l}\text { How successful do you think you were in accomplishing the goals of } \\
\text { the task set by the experimenter (or yourself)? How satisfied were } \\
\text { you with your performance in accomplishing these goals? }\end{array}$ \\
\hline $\begin{array}{c}\text { Frustration } \\
\text { Level (FR) }\end{array}$ & Low/High & $\begin{array}{l}\text { How hard did you have to work (mentally and physically) to } \\
\text { accomplish your level of performance? }\end{array}$ \\
\hline Effort (EF) & Low/High & $\begin{array}{l}\text { How insecure, discouraged, irritated, stressed and annoyed versus } \\
\text { secure, gratified, content, relaxed and complacent did you feel during } \\
\text { the task? }\end{array}$ \\
\hline
\end{tabular}

Source: (Hart \& Staveland, 1988) 
Table 1 helps to know the meaning each the rating scale. These scales lead the respondents to know how much stress they have. In the questionnaire there will be two parts. First, the respondents will be given 6 questions about MD, PD, TD, $\mathrm{OP}, \mathrm{EF}$, and FR.

Second, there will be 15 options lead the respondents to choose one from two options which make them feel stresser. The way of choosing between two options by circling one of them. From those answers lead the analyzer can be analizing which are the anwers that make the respondents more stress and how stressed they are.

b. Weighting

First of all, after getting the rating scale of NASA-TLX from the respondents based on the questionnaire, there are three importaint steps to get mean weighted workload, which are:

- Count products

Product is obtained by multiplying the rating by the factor weight for each descriptor

$$
\text { Product }=\text { Rating } x \text { Workload }
$$

- Count weighted workload (WWL)

WWL calculation is obtained by summing the products value

$$
W W L=\text { sProducts }
$$

- Count average of WWL The average of WWL is obtained by dividing the WWL by the total weight

$$
\text { core }=\frac{\sum(\text { weight } x \text { rating })}{15}
$$

This average of WWL will be known as the value of workers' mental workload.
- Interpretation of the value of the results

Based on Hart and Staveland research, NASA-TLX method, workload scores can be grouped into three parts those are scored more than 80, it means the workers do very heavy workload. Second score is $50-80$ which means that the workers do hard work. Third, $<50$ means workload is very easy.

NASA-TLX respondents were workers whose works on production department which is in packaging division. There were 30 respondents whose fill the questionnaire.

2. RULA (Rapid Upper Limb Assessment) is a method used to identify the upper body disorders or MSDs.

3. REBA (Rapid Entire Body Assessment) is a method used to identify work postures, determine safety and comfort of workers, and give improvement to recommend better body postures for workers with bad postures.

RULA and REBA respondents were several workers on processing department (contains weighing and producing) who really need futher investigation on how they do their works everyday and have to change their posture during work if needed.

\section{RESULT AND DISCUSSION}

This discussion is divided into two parts:

1. First, about mental workload, sometimes workers do not reach daily target that possibly causes lots of loss for the company, so this case must be solved. In this case, the first thing to do is counting the ratings from the questionnaire. 
Table 2. NASA-TLX RATING

\begin{tabular}{|c|c|c|c|c|c|c|}
\hline \multirow{2}{*}{$\begin{array}{l}\text { Respondent } \\
\text { Number }\end{array}$} & \multicolumn{6}{|c|}{ NASA-TLX RATING } \\
\hline & MD & PD & TD & OP & EF & FR \\
\hline 1 & 50 & 30 & 50 & 85 & 80 & 50 \\
\hline 2 & 50 & 70 & 80 & 75 & 70 & 20 \\
\hline 3 & 50 & 80 & 80 & 80 & 70 & 50 \\
\hline 4 & 70 & 80 & 95 & 85 & 100 & 50 \\
\hline 5 & 90 & 100 & 100 & 90 & 100 & 90 \\
\hline 6 & 70 & 70 & 50 & 80 & 70 & 40 \\
\hline 7 & 80 & 80 & 50 & 85 & 100 & 40 \\
\hline 8 & 95 & 100 & 80 & 90 & 70 & 30 \\
\hline 9 & 80 & 85 & 70 & 90 & 95 & 60 \\
\hline 10 & 90 & 90 & 70 & 95 & 95 & 40 \\
\hline 11 & 90 & 100 & 50 & 90 & 100 & 50 \\
\hline 12 & 80 & 90 & 90 & 90 & 80 & 20 \\
\hline 13 & 80 & 80 & 80 & 100 & 80 & 30 \\
\hline 14 & 90 & 100 & 90 & 90 & 90 & 20 \\
\hline 15 & 80 & 95 & 75 & 80 & 90 & 50 \\
\hline 16 & 90 & 100 & 20 & 80 & 50 & 10 \\
\hline 17 & 80 & 85 & 75 & 80 & 80 & 40 \\
\hline 18 & 90 & 90 & 70 & 80 & 80 & 5 \\
\hline 19 & 95 & 80 & 80 & 80 & 80 & 50 \\
\hline 20 & 90 & 80 & 75 & 80 & 80 & 60 \\
\hline 21 & 75 & 60 & 70 & 90 & 100 & 80 \\
\hline 22 & 80 & 80 & 85 & 90 & 85 & 70 \\
\hline 23 & 80 & 70 & 80 & 90 & 85 & 60 \\
\hline 24 & 90 & 95 & 75 & 95 & 100 & 30 \\
\hline 25 & 95 & 100 & 50 & 95 & 90 & 50 \\
\hline 26 & 90 & 90 & 80 & 95 & 100 & 30 \\
\hline 27 & 90 & 95 & 85 & 90 & 90 & 15 \\
\hline 28 & 80 & 50 & 50 & 40 & 65 & 50 \\
\hline 29 & 90 & 100 & 80 & 100 & 100 & 80 \\
\hline 30 & 70 & 80 & 50 & 85 & 100 & 100 \\
\hline$\overline{\mathbf{X}}$ & 81 & 83.50 & 71.17 & 85.83 & 85.83 & 45.67 \\
\hline$\Sigma$ & 2430 & 2505 & 2135 & 2575 & 2575 & 1370 \\
\hline
\end{tabular}


Table 3. Weight

\begin{tabular}{|c|c|c|c|c|c|c|}
\hline \multirow{2}{*}{$\begin{array}{l}\text { Respondent } \\
\text { Number }\end{array}$} & \multicolumn{6}{|c|}{ FACTOR } \\
\hline & MD & PD & TD & OP & EF & FR \\
\hline 1 & 2 & 2 & 2 & 3 & 3 & 3 \\
\hline 2 & 1 & 4 & 2 & 4 & 4 & 0 \\
\hline 3 & 1 & 3 & 2 & 4 & 5 & 0 \\
\hline 4 & 2 & 2 & 2 & 4 & 5 & 0 \\
\hline 5 & 3 & 5 & 1 & 2 & 4 & 0 \\
\hline 6 & 0 & 3 & 2 & 5 & 4 & 1 \\
\hline 7 & 3 & 0 & 2 & 4 & 5 & 1 \\
\hline 8 & 1 & 4 & 3 & 5 & 2 & 0 \\
\hline 9 & 2 & 2 & 1 & 4 & 5 & 1 \\
\hline 10 & 1 & 3 & 2 & 4 & 5 & 0 \\
\hline 11 & 1 & 3 & 2 & 5 & 4 & 0 \\
\hline 12 & 3 & 5 & 1 & 3 & 3 & 0 \\
\hline 13 & 3 & 4 & 0 & 2 & 5 & 1 \\
\hline 14 & 2 & 3 & 2 & 5 & 3 & 0 \\
\hline 15 & 1 & 3 & 2 & 4 & 5 & 0 \\
\hline 16 & 2 & 2 & 2 & 5 & 4 & 0 \\
\hline 17 & 2 & 1 & 2 & 3 & 2 & 5 \\
\hline 18 & 1 & 3 & 2 & 5 & 4 & 0 \\
\hline 19 & 2 & 0 & 2 & 5 & 4 & 2 \\
\hline 20 & 3 & 3 & 1 & 3 & 5 & 0 \\
\hline 21 & 4 & 1 & 3 & 1 & 5 & 1 \\
\hline 22 & 2 & 3 & 1 & 4 & 5 & 0 \\
\hline 23 & 2 & 3 & 1 & 5 & 4 & 0 \\
\hline 24 & 2 & 2 & 2 & 4 & 5 & 0 \\
\hline 25 & 1 & 3 & 2 & 4 & 5 & 0 \\
\hline 26 & 1 & 4 & 3 & 3 & 4 & 0 \\
\hline 27 & 1 & 5 & 2 & 3 & 4 & 0 \\
\hline 28 & 2 & 2 & 2 & 4 & 5 & 0 \\
\hline 29 & 1 & 3 & 2 & 4 & 5 & 0 \\
\hline 30 & 1 & 0 & 4 & 3 & 5 & 2 \\
\hline$\Sigma$ & 53 & 81 & 57 & 114 & 128 & 17 \\
\hline
\end{tabular}

The data retrieved from respondents are different because every single worker thought differently about her or his job. But, the questionnaire has its rate from 0 until 100 with the range of 5 . After counting NASA-TLX Rating, we count the weight.

It helps the respondents to know the level of mental workload that they accumulate all these time. And next, measuring the weight after calculating the rate. The data displayed on Table 3 . 
Table 4. Average of WWLs

\begin{tabular}{|c|c|c|c|c|c|c|c|c|c|}
\hline \multirow{2}{*}{$\begin{array}{l}\text { Respondent } \\
\text { Number }\end{array}$} & \multicolumn{6}{|c|}{ PRODUCTS } & \multirow{2}{*}{ WWL } & \multirow{2}{*}{$\begin{array}{c}\text { AVERAGE OF } \\
\text { WWL }\end{array}$} & \multirow{2}{*}{ CLASSIFICATION } \\
\hline & MD & PD & TD & OP & EF & FR & & & \\
\hline 1 & 100 & 60 & 100 & 255 & 240 & 150 & 905 & 60.33 & HEAVY \\
\hline 2 & 50 & 280 & 160 & 300 & 280 & 0 & 1070 & 71.33 & HEAVY \\
\hline 3 & 50 & 240 & 160 & 320 & 350 & 0 & 1120 & 74.67 & HEAVY \\
\hline 4 & 140 & 160 & 190 & 340 & 500 & 0 & 1330 & 88.67 & VERY HEAVY \\
\hline 5 & 270 & 500 & 100 & 180 & 400 & 0 & 1450 & 96.67 & VERY HEAVY \\
\hline 6 & 0 & 210 & 100 & 400 & 280 & 40 & 1030 & 68.67 & HEAVY \\
\hline 7 & 240 & 0 & 100 & 340 & 500 & 40 & 1220 & 81.33 & VERY HEAVY \\
\hline 8 & 95 & 400 & 240 & 450 & 140 & 0 & 1325 & 88.33 & VERY HEAVY \\
\hline 9 & 160 & 170 & 70 & 360 & 475 & 60 & 1295 & 86.33 & VERY HEAVY \\
\hline 10 & 90 & 270 & 140 & 380 & 475 & 0 & 1355 & 90.33 & VERY HEAVY \\
\hline 11 & 90 & 300 & 100 & 450 & 400 & 0 & 1340 & 89.33 & VERY HEAVY \\
\hline 12 & 240 & 450 & 90 & 270 & 240 & 0 & 1290 & 86.00 & VERY HEAVY \\
\hline 13 & 240 & 320 & 0 & 200 & 400 & 30 & 1190 & 79.33 & HEAVY \\
\hline 14 & 180 & 300 & 180 & 450 & 270 & 0 & 1380 & 92.00 & VERY HEAVY \\
\hline 15 & 80 & 285 & 150 & 320 & 450 & 0 & 1285 & 85.67 & VERY HEAVY \\
\hline 16 & 180 & 200 & 40 & 400 & 200 & 0 & 1020 & 68.00 & HEAVY \\
\hline 17 & 160 & 85 & 150 & 240 & 160 & 200 & 995 & 66.33 & HEAVY \\
\hline 18 & 90 & 270 & 140 & 400 & 320 & 0 & 1220 & 81.33 & VERY HEAVY \\
\hline 19 & 190 & 0 & 160 & 400 & 320 & 100 & 1170 & 78.00 & HEAVY \\
\hline 20 & 270 & 240 & 75 & 240 & 400 & 0 & 1225 & 81.67 & VERY HEAVY \\
\hline 21 & 300 & 60 & 210 & 90 & 500 & 80 & 1240 & 82.67 & VERY HEAVY \\
\hline 22 & 160 & 240 & 85 & 360 & 425 & 0 & 1270 & 84.67 & VERY HEAVY \\
\hline 23 & 160 & 210 & 80 & 450 & 340 & 0 & 1240 & 82.67 & VERY HEAVY \\
\hline
\end{tabular}




\begin{tabular}{|c|c|c|c|c|c|c|c|c|c|}
\hline \multirow{2}{*}{$\begin{array}{l}\text { Respondent } \\
\text { Number }\end{array}$} & \multicolumn{6}{|c|}{ PRODUCTS } & \multirow{2}{*}{ WWL } & \multirow{2}{*}{$\begin{array}{c}\text { AVERAGE OF } \\
\text { WWL }\end{array}$} & \multirow{2}{*}{ CLASSIFICATION } \\
\hline & MD & PD & TD & OP & EF & FR & & & \\
\hline 24 & 180 & 190 & 150 & 380 & 500 & 0 & 1400 & 93.33 & VERY HEAVY \\
\hline 25 & 95 & 300 & 100 & 380 & 450 & 0 & 1325 & 88.33 & VERY HEAVY \\
\hline 26 & 90 & 360 & 240 & 285 & 400 & 0 & 1375 & 91.67 & VERY HEAVY \\
\hline 27 & 90 & 475 & 170 & 270 & 360 & 0 & 1365 & 91.00 & VERY HEAVY \\
\hline 28 & 160 & 100 & 100 & 160 & 325 & 0 & 845 & 56.33 & HEAVY \\
\hline 29 & 90 & 300 & 160 & 400 & 500 & 0 & 1450 & 96.67 & VERY HEAVY \\
\hline 30 & 70 & 0 & 200 & 255 & 500 & 200 & 1225 & 81.67 & VERY HEAVY \\
\hline$\Sigma$ & 4310 & 6975 & 3940 & 9725 & 11100 & 900 & & & \\
\hline$\overline{\mathbf{x}}$ & 143.67 & 232.5 & 131.33 & 324.17 & 370 & 30 & & & \\
\hline
\end{tabular}


The data has been affected with many indicators which circled by the respondents, it looks like the 16th respondent which circled MD indicator twice, PD once, TD twice, OP five time, EF four time, and no one of FR.

There are 15 questions in the questionnaire. The respondents ordered to pick one out of two selections which makes more mental workload.
The table above this paragraph, explained that mental workload in packaging division in this company is very heavy. It can be seen by 21 workers are very exhausted with the mental workload out of total 30 workers in that station. 9 of them said that mental workload in this company is heavy enough.

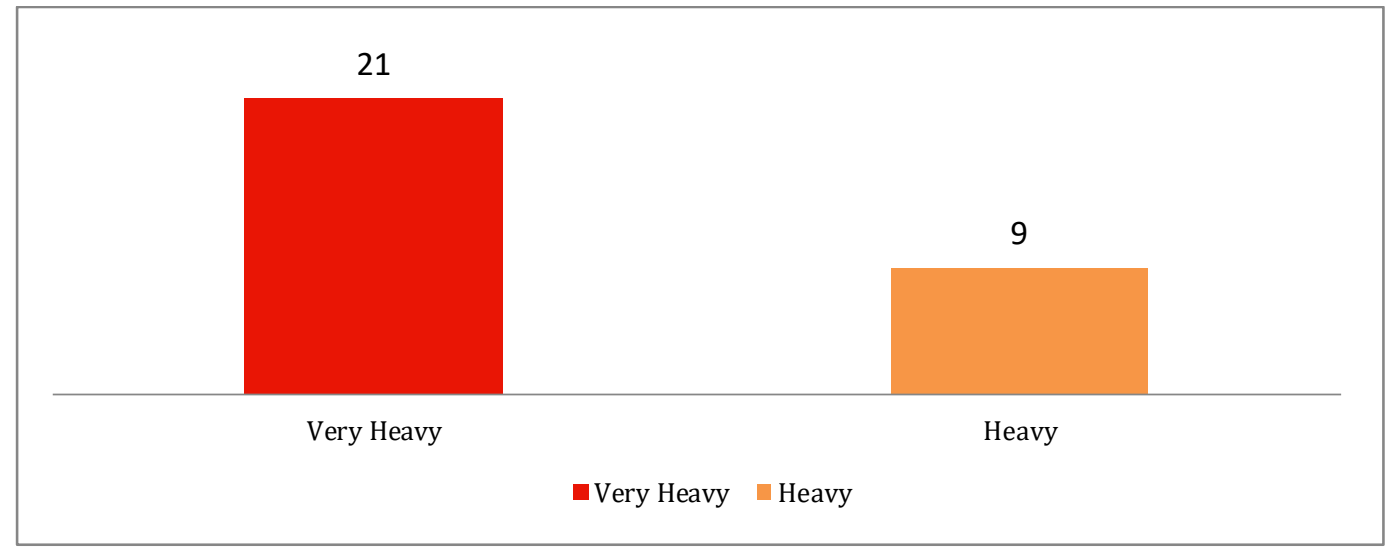

Figure 1. Classification of Mental Workload

Besides, the mental workload put them in very high pressured situation, but they satisfied and very pleased everytime they can complete daily target.

This data has been tested with result of significance is 0.44 and result of Kolmogorov-Smirnov is 0.86 so those numbers show that data is normal. Kolmogorov-Smirnov is one of various kind of tests which knowing the data normality. Based on that theory, the data will be normal if result of Kolmogorov-Smirnov is 0.05 . Morever, this data is taken at 10.00 . am until 11.30 a.m. So the workers are about to exhausted and need to have some time to break.

2. Second part of discussion tells about body posture of workers which determined by the way of workers do their works everyday. Several of them complained that their body is not well because of something they carry everyday (such as carrying kilograms of sacks).

Carrying kilograms of sacks, or anything during working, make the body easier to fatigue because the energy of the body is lower than the time when they enter the factory in the morning. In-depth analysis shows that the workers need to drink many cups of water, which might tells us that they are in fact is tired.

Based on the interview of several workers, they often feel tired when lifting a very heavy load. Therefore, this method helps the company to pay great attention to the load that the workers need to carry on daily basis, so RULA can be the best analysis to reveal the upper body health of every workers and the lack of MSDs around upper body because it determines the maximum weight that workers can lift continuously.

The picture above tells us that the worker has a curved back shape. The man stated that he usually restless because he feel something uncomfortable on his backbones.

In additon, he has a bent neck, that means the machine still not able to be adapted to average height of the 
workers. The weight of the sack (which is being inserted into the machine to insert the material inside the sack) is 17.05 kgs. It breaks the rule of maximum weight for healthy body. That sack has very heavy load in it. When workers carries a sack more than 10 kgs continuously, it is considered dangerous and damaging body posture.

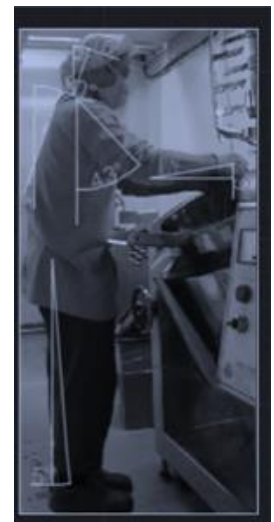

Figure 2. Worker Entering Material to a Machine

Table 5. Arm and Wrist Analysis with RULA

\begin{tabular}{ll}
\hline Upper arm score & $\mathbf{2}$ \\
\hline Lower arm score & 1 \\
\hline Wrist score & 2 \\
\hline Wrist twist score & 1 \\
\hline Posture A score & $\mathbf{3}$ \\
\hline Muscle use score & 0 \\
\hline Force / load score & 3 \\
\hline Arm and wrist score & $\mathbf{6}$ \\
\hline
\end{tabular}

Those scores tell us that the final score from this case is 7. It means the man needs to be investigated very soon and change his posture for a better body. Futhermore, his final work, such as entering the ingridients of some make up products to the machine so he will decrease the level of pouring the ingridients out of the machine, will be more satisfy as he will do his job better with correct body posture.
Table 6. Neck, Trunk, and Leg Analysis with RULA

\begin{tabular}{ll}
\hline Neck score & 3 \\
\hline Trunk score & 3 \\
\hline Leg score & 1 \\
\hline Posture B score & $\mathbf{4}$ \\
\hline Muscle use score & 0 \\
\hline Force / load score & 3 \\
\hline Neck, trunk, and leg score & $\mathbf{7}$ \\
\hline
\end{tabular}

Besides RULA, there is another body analysis method called REBA. This analysis can determine the lack of MSDs in the entire body.

The picture shows that a worker is lifting $20 \mathrm{kgs}$ of powder material, so he uses all of his energy to carry the sack. This action encourage him to use his entire body such as hands, legs, upper body, head, and almost entire body parts.

This action leads him to obtain MSDs, because he lift dozens of sacks daily during 8 hours of work. His body posture of work is not ideal posture to lift goods. Morever, body muscles look too tense around hands, legs, back bones, etc. It is not good if workers do it everyday because it can cause damage to their body.

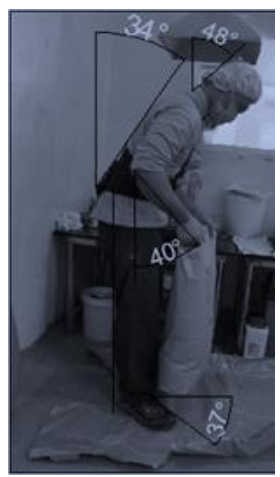

Figure 3. Worker Lifting a Sack of Powder

Although he is wearing something that looks like body crutch around his stomach, it is not helpful because it is not support his entire body. It will help if the body crutch can secure the worker entire body, so it can decrease level of MSDs injury in the worker. 
Table 7. Neck, Trunk, and Leg Analysis with REBA

\begin{tabular}{ll}
\hline Neck score & 2 \\
\hline Trunk score & 3 \\
\hline Leg score & 1 \\
\hline Force or Load Score & 3 \\
\hline Score A & $\mathbf{7}$ \\
\hline
\end{tabular}

Table 8. Arm and Wrist Analysis with REBA

\begin{tabular}{ll}
\hline Upper arm score & 2 \\
\hline Lower arm score & 2 \\
\hline Wrist score & 2 \\
\hline Coupling score & 1 \\
\hline Score B & 5 \\
\hline
\end{tabular}

Table 9. REBA Final Score

\begin{tabular}{lc}
\hline Score C & 9 \\
\hline Activity Score & 1 \\
\hline REBA final score & $\mathbf{1 0}$ \\
\hline
\end{tabular}

Table 7, 8 and 9 tell us that those are how to assess entire body using the REBA method. First, fill the neck, trunk, and leg score by seeing entire body of the worker, as can be seen with take a picture of the worker or from video. After that, assess the arm and wrist the worker by calculate the upper arm score, lower arm score, wrist score, and score B.

Futhermore, assess the score $\mathrm{C}$, activity score, and REBA final score. So, it can be perfectly calculated to measure the final score.

The final score is 10 , it means that everything the workers do are too risky to his body. 10 means he needs to improve his posture during work immediately.

Morever, the company needs to buy some hydrolic trolleys for every work station, so workers don't need to lift it up by themselves.

\section{CONCLUSION}

1. PT. XYZ needs to take care more about their workers health, because several workers in the processing department have MSDs
2. The existing postures, as calculated by RULA and REBA, have to be changed soon in order to have healthier body

3. A worker who lifting $20 \mathrm{kgs}$ of sack everyday have unhealthy body. Lifting something that huge can cause the damage of mucles and bones. Then, it is so much better if company gives hydrolic trolley in every station on the processing department, so they do not need to lift materials weighed more than $10 \mathrm{kgs}$.

4. A worker who does RULA assessment has a curved backbones, it is caused by lifting more than $10 \mathrm{kgs}$ daily. He needs to change his posture immediately and go to doctor to check his condition.

\section{REFERENCES}

[1] Sutalaksana, I. Z., Anggawisastra, R. and Tjakraamadja, J. H. 1979. Teknik Tata Cara Kerja. Departemen Teknik Industri ITB : Bandung.

[2] Fernandez, Jeffrey E. and Goodman, Michael. 1998. Ergonomics in The Workplace. Exponent Health Group: Alexandria, Virginia.

[3] U.S. Department of Labor. 2000. Ergonomics: The Study of Work (OSHA 3125). Occupational Safety and Health Administration (OSHA), p.1.

[4] Halim, I., Omar, A.R. \& Saad, N.H. 2005. Ergonomic Assessment to Identify Occupational Risk Factor in Metal Stamping Industry. NAME 05, 2005.

[5] Putri, D.L. 2008. Gambaran Kualitas Hidup Lanjut Usia yang Tinggal di PSTW Yogyakarta Unit Budi Luhur. Universitas Gajah Mada: Yogjakarta.

[6] Sue Hignett and Lynn McAtamney. 2000. Rapid Entire Body Assessment 
(REBA), Applied Ergonomics 31 (2000), pp. 201-205.

[7] Lynn McAtamney and E Nigel Corlett,. 1994. RULA: a survey method for the investigation of world-related upper limb disorders. Applied Ergonomics 1994. 24(2), pp. 9199.
[8] Hart, Sandra G. and Staveland, Lowell E. 1988. Development of NASA-TLX (Task Load Index): Result of Empirical and Theoretical Research.

[9] Hancock, P., and Meshkati, N. 1988. Human Mental Workload. Netherlands: Elsevier Science Publisher B.V. 